Journal of Animal and Veterinary Advances 11 (7): 916-918, 2012

ISSN: $1680-5593$

(C) Medwell Journals, 2012

\title{
Polymorphism Analysis on the Second Intron of the $G H$ Gene in Chinese Donkeys
}

\author{
${ }^{1}$ Wenjin Zhu, ${ }^{1}$ Yongmei Su, ${ }^{2}$ Yanhua Ma, ${ }^{1} \mathrm{Jing} \mathrm{Ni},{ }^{3}$ Xuemin Guan and ${ }^{1} \mathrm{Jianhua} \mathrm{Wu}$ \\ ${ }^{1} \mathrm{Key}$ Lab of Preventive Veterinary Medicine, College of Animal Science and Technology, \\ ${ }^{2}$ E\&A College, ${ }^{3}$ College of Life Science, Hebei Normal University of Science and Technology, \\ 066600 Qinhuangdao, Changli, Hebei Province, P.R. China
}

\begin{abstract}
To reveal the genetical diversity of different donkey breeds at molecular level and provid some bases for the breed resource evaluation and utilization of donkeys in China, polymorphism of the second intron of the GH gene was analysised by PCR-SSCP in the seven donkey breeds (LX, GZ, XJ, GL, HB, DZ, JN). The results showed three haplotypes with the percentage of $1.7 \%$ in 174 samples were obtained, the haplotype diversity was high as 0.678 and 0.542 for the Linxian and Huaibei donkey and low as 0.077 for Xingiiang donkey with that of 0.409 and 0.462 for Guangling donkey and Guanzhong donkey, respectively with that of 0.355 and 0.304 for Dezhou donkeys and Jinnan donkeys, respectively. The amplified fragments of A and B haplotypes were cloned and sequenced. The result showed the fragments of B haplotypes had one substitution mutation at 735 site $(\mathrm{G} \rightarrow \mathrm{C})$, the fragments of A haplotypes had one substitution mutation at 869 site $(\mathrm{G} \rightarrow \mathrm{T})$. The results confirmed that there were polymorphisms in the second intron $(214 \mathrm{bp})$ of donkey $G H$ gene for the first time.
\end{abstract}

Key words: Donkey, GH gene, PCR-SSCP, genetics diversity, mutation, polymorphisms

\section{INTRODUCTION}

The Growth Hormone $(\mathrm{GH})$ is a single chain polypeptide hormone secreted by the anterior pituitary it plays an important role during animal growth and development, studies have shown that $G H$ gene consists of 5 exons and 4 introns in mammals and birds (De Noto et al., 1981; Woychik et al., 1982; Barta et al., 1991; Buggioti and Primmier, 2006) and is located on 19th chromosome in q26-qter band region (Hediger et al., 1990).

GH gene is the major gene controlling the level of $\mathrm{GH}$ secretion, regulating animal growth and development and other important physiological activities. At present, there are a lot of reports on associations of $G H$ gene polymorphism with production traits (Horvat and
Medrano, 1995; Yardibi et al., 2009; Nielsen et al., 1995 ) but the reports on $G H$ gene polymorphism in donkey is seldom.

To reveal the genetical diversity of chinese local donkey breeds at molecular level, the $G H$ gene sequences of the second intron in the 174 individuals of seven Chinese local donkey breeds were analysied by PCR-SSCP in this study. In order to provide reference for the protection of local donkey breeds germplasm.

\section{MATERIALS AND METHODS}

Genomic DNA extraction: The blood samples of 174 donkeys of 7 local breeds (Table 1) were collected and genomic DNA extracted by applying convention method.

\begin{tabular}{lccll}
\multicolumn{5}{l}{ Table 1: The number, collection location and origin of samples of donkey breeds } \\
\hline Breeds & Code & No. of individuals & Collection location & Localities \\
Guangling & GL & 26 & Guangling town & Guangling and Lingqiu of Shanxi province \\
Linxian & LX & 8 & Linxian Shanxi & Linxian West of Shanxi province \\
Jinnan & JN & 28 & Wenxi town & Yuncheng and Linfen of Shanxi province \\
Guanzhong & GZ & 32 & Yangling Shaanxi & Guanzhong plain of Shaanxi province \\
Xinjiang & XJ & 26 & Yining city Xinjiang & Kashi region, Xinjiang Autonomous region \\
Dezhou & DZ & 36 & Lucheng Shanxi & The towns along Bohai sea at Lubei plain in \\
& & & & Shandong province \\
Huaibei & HB & 18 & Mengcheng Anhui & Huaibei city, Anhui province
\end{tabular}

Corresponding Author: Wenjin Zhu, Key Lab of Preventive Veterinary Medicine, College of Animal Science and Technology, Hebei Normal University of Science and Technology, 066600 Qinhuangdao, Changli, Hebei Province, P.R. China 
PCR amplification: Through using Primer3.0, the second intron primers of $G H$ gene were designed according to the DNA sequence of Chinese dwarf horse (DQ845298) and Thoroughbred (DQ845297), the upstream primer is 5'-CT GGCTGCTGACACCTACAA-3', the downstream primer is 5'-CGCTCCTGGGAGAAAGAAC-3'.

The PCR amplification was carried out in a total volume of $25 \mathrm{uL}(10 \times$ buffer $2.5 \mathrm{~mL}$, dNTPs $2 \mathrm{uL}$, mix primer $2 \mathrm{uL}$, Taq DNA polymerase $0.2 \mathrm{uL}$, template DNA 2 and $14.8 \mathrm{uL}$ sterilization distilled water). PCR was performed under the following reaction procedure: $94^{\circ} \mathrm{C}$ denaturation for $2.5 \mathrm{~min} \rightarrow 32 \times\left(94^{\circ} \mathrm{C} 40 \mathrm{sec}, 58^{\circ} \mathrm{C} 40 \mathrm{sec}\right.$, $\left.72^{\circ} \mathrm{C}, 1 \mathrm{~min}\right) \rightarrow 72^{\circ} \mathrm{C}$ extension $10 \mathrm{~min}$.

The genotype identification with PCR-SSCP and sequencing confirmation: The genotype of the product of PCR was identified by SSCP procedure as follows, $3 \mathrm{uL}$ PCR product was mixed with $6 \mathrm{uL}$ loading buffer, heating at $98^{\circ} \mathrm{C}$ for $10 \mathrm{~min}$ then bathing in ice for $10 \mathrm{~min}$ and visualizing with $12 \%$ non-denatured polyacrylamide gel electrophoresis by the silver nitrate dyeing. The PCR fragment were purified with a DNA Fragment Purification kit (TaKaRa Biotechnolgy Dalian Co., Ltd.) then cloned and sequenced by Shanghai Biology Engineering Technology Ltd. (Beijing Sequencing Department).

Statistical analysis: The number of haplotype frequency and the diversity of haplotype were analysed by Microsoft Excel analysis. The diversity of haplotype was calculated by the equation as follows:

$$
\mathrm{H}=\frac{\mathrm{n}\left(1-\sum \mathrm{x}_{\mathrm{i}}^{2}\right)}{(\mathrm{n}-1)}
$$

$\mathrm{H}=$ Haplotype diversity indices

$\mathrm{x}_{\mathrm{i}}=$ Means the haplotype ranks $\mathrm{i}$

\section{RESULTS AND DISCUSSION}

Haplotype distribution and frequency: The amplified products of the $G H$ gene second intron on 7 breeds were analysed by the SSCP (Fig. 1) there are three kinds of haplotypes were detected in the intron of $214 \mathrm{bp}$ and compared with the results of different haplotype after sequenceing, showed the A-type occur a mutation $(\mathrm{G} \rightarrow \mathrm{T})$ in 869 bp of the donkey $G H$ gene, the B-type occur a mutation $(\mathrm{G} \rightarrow \mathrm{C})$ in 735 bp (Fig. 2) and both the mutations are transversions with homology $99 \%$. Table 2 shows the detected haplotype and its frequency in different donkey breeds there 131 haplotype of A was detected in 174 samples, the haplotype of $\mathrm{A}$ and its frequence is the most in 7 breeds except LX donkey that showed it is the shared haplotype. The haplotype of $\mathrm{B}$ was detecteded in 4 individual from 4 donkey breeds (GZ, LX, XJ and HB) it was small with only one individual detected in each breed. Haplotype $\mathrm{C}$ was detected in all the donkey breeds except $\mathrm{XJ}$ donkey and its frequency range was $0.179-0.5$ in 7 breeds.

Haplotype diversity: Table 3 shows the genetic diversity indices of 7 Chinese local donkeys, the the genetic diversity indices of LX donkey was the highest (0.678) showing its genetic diversity is the most abundant, XJ dinkey is the lowest (0.077) its genetic diversity is lack relative while the genetic diversity indices of GL and GZ is closer, 0.409 and 0.462 , respectively which is consistent with the record that Shanxi large-sized donkey breeds are local variety and formed after the Guanzhong donkey distributes to these areas (Zhang and Zhu, 1986).

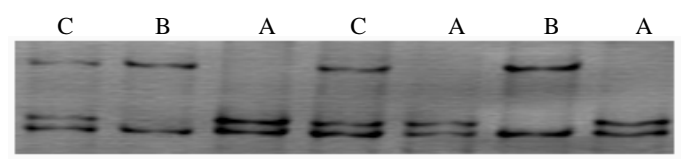

Fig. 1: Detection of SSCP in the intron 2 of the donkey GH gene

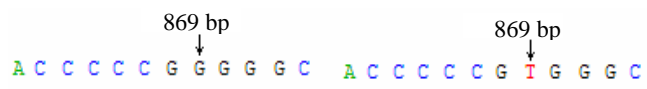
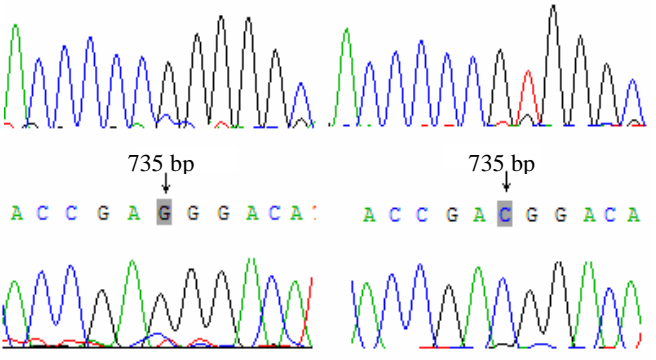

Fig. 2: Chromatograms showing sequence variations in 735 and 869 bp sites of donkey $G H$ gene intron 2

\begin{tabular}{|c|c|c|c|c|c|c|c|c|}
\hline \multirow[b]{2}{*}{ Haplotype } & \multicolumn{8}{|l|}{ Breeds } \\
\hline & $\mathrm{DZ}$ & GZ & GL & $\mathrm{LX}$ & $\mathrm{JN}$ & $\mathrm{XJ}$ & $\mathrm{HB}$ & Total \\
\hline $\mathrm{A}$ & $28 / 0.778$ & $22 / 0.688$ & $19 / 0.731$ & $3 / 0.375$ & $23 / 0.821$ & $25 / 0.961$ & $11 / 0.611$ & $131 / 0.740$ \\
\hline B & - & $1 / 0.031$ & - & $1 / 0.125$ & - & $1 / 0.038$ & $1 / 0.056$ & $4 / 0.022$ \\
\hline $\mathrm{C}$ & $8 / 0.222$ & $9 / 0.281$ & $7 / 0.269$ & $4 / 0.500$ & $5 / 0.179$ & - & $6 / 0.333$ & $39 / 0.224$ \\
\hline Total & $36 / 1.000$ & $32 / 1.000$ & $26 / 1.000$ & $8 / 1.000$ & $28 / 1.000$ & $26 / 1.000$ & $18 / 1.000$ & $174 / 1.000$ \\
\hline
\end{tabular}

Table 2: Haplotype and frequency in the intron of the 7 donkeys $G H$ gene 


\begin{tabular}{|c|c|c|c|c|}
\hline Breeds & Samples & $\begin{array}{c}\text { No. of } \\
\text { haplotype }\end{array}$ & $\begin{array}{l}\text { Haplotype } \\
\text { proportion }\end{array}$ & $\begin{array}{c}\text { Haplotype } \\
\text { diversity }\end{array}$ \\
\hline $\mathrm{DZ}$ & 36 & 2 & 0.056 & 0.355 \\
\hline GZ & 32 & 3 & 0.093 & 0.462 \\
\hline GL & 26 & 2 & 0.077 & 0.409 \\
\hline LX & 8 & 3 & 0.375 & 0.678 \\
\hline $\mathrm{JN}$ & 28 & 2 & 0.071 & 0.304 \\
\hline $\mathrm{XJ}$ & 26 & 3 & 0.115 & 0.077 \\
\hline$\underline{\mathrm{HB}}$ & 18 & 3 & 0.167 & 0.542 \\
\hline
\end{tabular}

It is clear that the genetic diversity is not significantly in 7 donkey breeds whether it is related to donkey production traits still needs further study.

\section{CONCLUSION}

This experiment was conducted to study the polymorphism on intron 2 of $G H$ gene in donkey. Three haplotypes were found in 7 China local donkeys but the genetic diversity is not significantly in 7 donkey breeds whether it is associations with donkey production traits still needs further study after expanding number of donkey breeds and samples.

\section{ACKNOWLEDGEMENTS}

This research was supported by the Natural Science Fund of Hebei province (C2007000739), Hebei Normal University of Science and Technology doctoral Start Fund (2006D006).

\section{REFERENCES}

Barta, A., R.I. Richards and J.D. Baxter, 1991. Primary structure and evaluation of rat growth hormone gene. Proc. Natl. Acad. Sci., 78: 4867-4871.
Buggioti, L. and C.R. Primmier, 2006. Molecular evolution of the avian growth hormone gene and comparison with it smammalian counterpart. J. Evol. Biol., 19: 844-854.

De Noto, F.M., D.D. Moore and H.M. Goodman, 1981. Human growth DNA sequence and mRNA structure: Possible alternative splicing. Nucleic Acids Res., 97: 3719-3730.

Hediger, R., S.E. Johnson, W. Barendse, R.D. Drinkwater, S.S. Moore and J. Hetzel, 1990. Assignment of the growth hormone gene locus to 19q26-qter in cattle and to $11 \mathrm{q} 25$-qter in sheep by in situ hybridization. Genomics, 8: 171-174.

Horvat, S. and J.F. Medrano, 1995. Interval mapping of high growth (hg), a major locus that increases weight gain in mice. Genetics, 139: 1737-1748.

Nielsen, V.H., N.J. Larsen and N. Agergaad, 1995. Association of DNA polymorphism in the growth hormone gene with basal-plasma growth hormone concentration and production trait in pigs. J. Anim. Breed. Genet., 112: 205-212.

Norio, K., N. Asako and O. Hisato, 2003. DNA polymorphism in the chicken growth hormone gene association with egg production. Anim. Sci., 74: 243-244.

Woychik, R.P., S.A. Camper, R.H. Lyons, S. Horowitz and E.C. Goodwin et al., 1982. Cloning and nucleotide sequencing of the bovine growth hormone gene. Nucleic Acids Res., 10: 7197-7210.

Yardibi, H., G.T. Hosturk, I. Paya, F. Kaygisiz, G. Ciftioglu, A. Mengi and K. Oztabak, 2009. Associations of growth hormone gene polymorphisms with milk production traits in South Anatolian and East Anatolian red cattle. J. Anim. Vet. Adv., 8: 1040-1044.

Zhang, Z.G. and X.H. Zhu, 1986. The History of Chinese Animal Husbandry. Scientific Press, Beijing. 